\title{
LXXI. On the expansive action of steam in some of the pumping engines on the Cornish Mines
}

\section{William Jory Henwood F.G.S.}

To cite this article: William Jory Henwood F.G.S. (1839) LXXI. On the expansive action of steam in some of the pumping engines on the Cornish Mines, Philosophical Magazine Series 3, 14:92, 481-491, DOI: $10.1080 / 14786443908649801$

To link to this article: http://dx.doi.org/10.1080/14786443908649801

册 Published online: 01 Jun 2009.

Submit your article to this journal $[\pi$

Џll Article views: 2

Q View related articles $\square$ 


\section{PHILOSOPHICAL MAGAZINE}

AND

\section{JOURNAL OF SCIENCE,}

SUPPLEMENT TO VOL. XIV. THIRD SERIES.

LXXI. On the Expansive Action of Stecum in some of the Pumping Engines on the Cornish Mines. By William Jory Henwood, F. G.S., Secretary of the Royal Geological Society of Corntoall, H. M. Assay-Master of Tin in the Duchy of Cornwall*.

THE experiments which it is my purpose to describe, were instituted with a view to the determination of the quantity of steam employed, and the mode of its distribution on the working stroke; the duty performed with a given quantity of fuel; and the work accomplished for a certain expense.

I. The quantity of steam employed, and the mode of its distribution on the roorking stroke, were approximated to by the use of an indicator, lent me for the purpose by Robert Were Fox, Esq. It copsists of a brass cylinder about 11 inches long, and 1.6 inch in diameter, open at both ends, and accurately fitted with a piston, which, when at rest, is retained near the middle of the cylinder by a spiral spring, of which one end is attached to the piston, and the other to the top of the cylinder: the upper extremity of the piston-rod is provided with a receptacle for a pencil. A tapered stop-cock is fixed on the lower end of the cylinder, and is introduced into the grease-hole or other aperture in the cylinder-cover of any engine on which the indicator is placed. A light frame of wood, about 18 inches long and 4 inches wide, is fastened to the top of the indicator-cylinder, and in it a small board slides horizontally in grooves.

During the working stroke of the engine a direct motion is given to the slider by means of a string which passes over a pulley, and is connected with the radius-rod of the parallel motion. Its return is effected by the action of a counterpoise suspended over a similar small wheel. On this moveable board a piece of paper is firmly secured, and a pencil is placed on the top of the piston-rod of the indicator.

* The Telford Medal of the Institution of Civil Engineers was awarded to this communication, which appears in the second volume of their Transactions.

Phil. Mag. S. 3. Vol. 14. No. 92. Suppl. July, 1839. 2 I 
Let us now examine the operation of a single-acting engine, and the movements of an indicator fixed on it.

Every thing being at rest, the piston of the engine at the top of the cylinder, and the point of the pencil standing at A, (in the figure below) steam is admitted from the boiler above the piston of the engine; the piston of the indicator is forced upwards, and the line A B is described by the pencil. The engine now begins to move, but so slowly that the steam enters from the boiler more rapidly than the piston recedes before it; its pressure in the cylinder, therefore, still increases, and the piston of the indicator continues to rise: but as the working stroke of the engine commences, the slider moves in the direction $\mathrm{GF}$, and the compound of the two motions generates the line BC. At $\mathrm{C}$ the space left by the descent of the piston is exactly filled by the steam, which enters from the boiler in the same time; the indicator-piston, therefore, does not stir; but as the engine moves, the slider still advances in the same direction, $(\mathrm{GF}$, and the horizontal line $\mathrm{C} c$ is produced. The piston now acquires speed, whilst the steam (in the boiler having expanded) enters the cylinder with diminished velocity, and is insufficient to fill the enlarging space and still re-

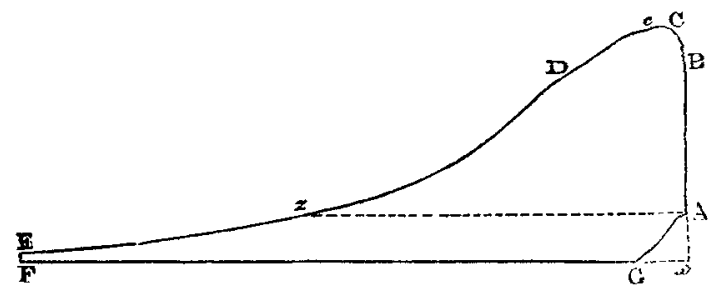

tain the same density: it therefore expands, and the piston of the indicator descends, whilst the slider still moves in the same direction, and the curve $c \mathrm{D}$ is delineated. At $\mathrm{D}$ the steam valve, through which the steam from the boiler enters the cylinder, is closed, but the piston of the engine still descends by virtue of the elasticity of the steam already introduced, and of the momentum acquired by the moving parts of the machine. Whilst the steam expands, the indicator-piston descends, and as the same horizontal motion of the slider still continues, the parabolic curve DE is made by the pencil.

The equilibrium valve, which connects the upper part of the cylinder with the lower, is now opened; and as the steam thus presses equally on both sides of the piston, the working stroke terminates, and the return stroke is made: the motion of the slider is at the same time reversed. 
But when this valve is opened, the pipe which connects the top of the cylinder with the bottom, and consequently a larger space, is open to the steam, and as the slider remains for the instant stationary, the indicator-piston descends through the small vertical line EF.

The return stroke is effected by the weight of the pumprods alone; the pressure of the steam contained in the cylinder, therefore, remains unaltered, the indicator-piston is unmoved, and the line FG, described by the pencil, is perfectly horizontal.

But shortly before the termination of the return stroke, the equilibrium valve is closed, and the steam in the cylinder not being of sufficient elasticity to sustain the load of the engine, that portion of it which is contained between the upper surface of the piston and the cylinder-cover is compressed between them by the ascent of the former, until it is of force enough to support that weight; the return stroke is thus terminated, and the engine stops an instant or two before it commences another working stroke. This compression of the steam contained in the upper part of the cylinder forces the indicator-piston upward, and the resultant of this gradual elevation, and of the continued retrograde motion of the slider, is the small curved line GA, the pencil at the end of the stroke returning to and standing at $A$.

It is evident that the form of the portion $\mathrm{ABC} c \mathrm{D}$, which is produced during the admission of steam from the boiler on the piston, must depend on the load of the engine, its size, the dimensions of the steam valve, the pressure of steam in the boiler, and the capacity of the boiler itself, and that it will, therefore, vary as these particulars may differ.

The part $\mathrm{DzE}$ will deviate from a true parabola only when the steam in the cylinder is heated by being surrounded by a steam-case, or jacket, or by flues containing warm air, or cooled by the influence of the circumambient medium; consequently it will be generally pretty much alike in all cases. The same reasons and influences are equally applicable to the small and nearly vertical line EF, and to the longer horizontal one FG.

But, theoretically speaking, the curve GA is of more importance than any other portion of the figure; because it clearly shows what proportion of the working stroke is performed by the beneficial influence of working expansively.

For were the steam from the boiler admitted on the piston during the whole of the working stroke, or the pressure of the steam (if worked expansively) sufficient to support the load at the termination thereof; then the line FG, described 


\section{Mr. Henwood on the Cornish Pumping-Engines.}

by the return stroke, would be prolonged horizontally until it intersected an extension of the vertical line $\mathrm{AB}$ at $x$; at which point the pencil would rest at the end of the return stroke, and the instant the equilibrium valve closed the engine would stop. But it has been seen that the engine continues to move, and that the indicator-piston rises and generates the curve GA, after that valve is closed: which circumstances clearly demonstrate that the steam included between the cylinder-cover and the upper surface of the piston, is mean while undergoing compression; and that its elasticity both at the conclusion of the working stroke, and at the closing of the equilibrium valve, was insufficient to sustain the load. And it follows, that the portion of the working stroke which has been performed after the steam has expanded so much as to be unequal to supporting the burden, must have been accomplished by the momentum acquired in the early part of the stroke. When the pencil rests at $A$, the force of the steam balances the load of the engine; for the piston is never permitted to rise so far as to touch the cylinder-cover. If, therefore, from $A$ a line be drawn parallel to $F G$, until it cuts the parabolic curve DE, the point of intersection, $z$, will be at that part of the stroke where the (simple) elasticity of the steam and the load of the engine are exactly in equilibrio; and the portion $\approx \mathrm{E}$, (described after the steam has so far expanded as to be insufficient to support the burden,) will denote the amount of benefit obtained by working expansively.

The only case in which I have been able to submit the results thus obtained with the indicator to a direct comparison with the quantity of water evaporated in the boilers was at Huel Towan, where $847 \cdot 5$ cubic feet of water were converted into steam. This would give 342,858 feet of steam of a pressure of $64 \cdot 1 \mathrm{lbs}$. on the square inch, (or $49 \cdot 1 \mathrm{lbs}$. on the inch above the atmosphere,) the mean pressure in the boiler during the experiment, or $2,153,647$ cubic feet of the pressure of $10.2 \mathrm{lbs}$. on the inch $*$. The capacity of the cylindernozles and other parts of the engine which required to be filled with steam from the boiler at every stroke, was 355.57 cubic feet $f$, and the number of strokes made during the observations 7881. Therefore, if it were indispensable for the steam on the piston, at the termination of the working stroke, to be of elasticity sufficient to sustain the load of the engine, piston.

* 10.2 Ibs. was the load of the engine per square inch of the area of the

+ Brewster's Edinburgh Journal of Science, O. S. IX. p. 160; from this, however, the dimensions of the piston-rod, probably about 2 cubic feet, should be deducted. 
$2,802,247$ cubic feet (of a pressure of $10.2 \mathrm{lbs}$. on the inch) would have been requisite; whereas but $2,153,647$ cubic feet only could be obtained from the quantity of water evaporated. Consequently but the 0.768 th of the contents of the cylinder, \&c., could, on an average, have been filled with steam of that force; and the remaining 0.232 of the stroke must therefore have been performed by virtue of the momentum acquired by the machine in the early part of the working stroke.

This 0.232 part of the whole is therefore the benefit obtained by working the steam expansively; although the result obtained by the indicator exhibits a still greater (about 0.388) advantage. The cause of this difference it is not very easy to assign satisfactorily. It is just possible that it may be from the fluctuating pressure of the steam (from $77 \cdot 25$ to $47 \cdot 22 \mathrm{lbs}$. on the inch) during the experiment, giving a result differing on a mean more than $61.8 \mathrm{lbs}$. on the inch, (the force when the curve represented in the figure p. 482 was obtained,) does from the average elasticity during the observation $(64 \cdot 1 \mathrm{lbs}$.$) .$ But perhaps it may more probably be from the steam, even when expanded to a less forcethan $10.2 \mathrm{lbs}$. on the inch, still exercising a beneficial influence in assistance of the momentum by which the latter part of the working stroke is performed.

In a first attempt at such a comparison, which I believe is here made, it may perhaps excite no great surprise that there is not a more exact coincidence between the results obtained by these very different modes of inquiry.

II. The duty performed with a given quantity of fuel.-The experiments with an object to determining the duty performed with a known quantity of fuel, were made on Wilson's engine at Huel Towan; on Swan's engine at Binner Downs Mine; and on Hudson's engine at East Crinnis Mine*. These were among the best engines in Cornwall, and they were selected on account of the very varied circumstances under which they worked.

At Huel Towan the cylinder with its cover and bottom were surrounded with a case or jacket, filled with dense steam from the boiler; and these, with the steam-pipes, nozles, \&c., were covered with saw-dust from 16 to 20 inches deep. The boilers had a layer of ashes, of about the same thickness, placed on them.

There was no steam-case at Binner Downs, but there were small fires on each side of the cylinder, and the flues from them were carried spirally round it; another little fire was placed beneath the steam-nozle, from the boiler, and its flue

* The engineers were respectivelý, Mr. Grose, Messrs. Gregor and Thomas, and Mr. Sims. 


\section{6}

Mr. Henwood on the Cornish Pumping-Engines.

was passed over the cylinder-cover; under the steam-pipe from the boiler was a similar fire, and its smoke was conveyed round the pipe for some distance. Such parts of the engine as were not enveloped by the flues were surrounded with saw-dust*, and the boilers were covered with ashes as at Huel Towan.

The engine at East Crinnis had neither steam nor heated air passed round it; but every part which contained dense steam was surrounded with a very thick covering of saw-dust, and the boilers were protected in a similar manner to those of the other engines.

On all these the indicator was placed; and also on Burn's engine at Binner Downs, which is inclosed in a similar manner to Swan's engine on the same mine, already mentioned; and on Trelawny's and Borlase's engines at Huel Vor, both which have steam-cases and other coverings like that described at Huel Towan. On the duty of these no experiments were made.

Table I.-(Constants.)

Dimensions of the Engines, and amount of their loads.

\begin{tabular}{|c|c|c|c|c|c|c|c|c|c|c|}
\hline \multirow[b]{2}{*}{ Mines and Engines. } & \multirow{2}{*}{ 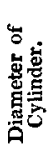 } & \multicolumn{2}{|c|}{ Stroke in } & \multicolumn{2}{|c|}{ Air-pump. } & \multicolumn{3}{|c|}{$\begin{array}{l}\text { Diameter of } \\
\text { valves. }\end{array}$} & \multirow[b]{2}{*}{$\begin{array}{l}\text { Total load } \\
\text { of the } \\
\text { Engine. }\end{array}$} & \multirow{2}{*}{ 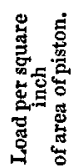 } \\
\hline & & $\begin{array}{c}\text { Cylin. } \\
\text { der. }\end{array}$ & Pump. & $\begin{array}{c}\text { Dia- } \\
\text { meter. }\end{array}$ & Stroke. & 喦 & 产竞 & 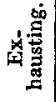 & & \\
\hline IIuel Towan, Wilson's & $\begin{array}{l}\text { In. } \\
80\end{array}$ & $\begin{array}{l}\text { Feet. } \\
10\end{array}$ & 8 & $\begin{array}{c}\text { Inches. } \\
\mathbf{3 6}\end{array}$ & $\begin{array}{l}\text { Feet. } \\
\mathbf{4}\end{array}$ & In. & $\begin{array}{l}\text { In. } \\
\text { 12 }\end{array}$ & In. & $\begin{array}{c}\text { lbs. } \\
68666 \cdot 4\end{array}$ & $\begin{array}{l}\text { lbs. } \\
10 \cdot 2\end{array}$ \\
\hline Binner Downs, Swan's & 70 & 10 & $7 \cdot 5$ & 33 & 4 & 9 & 12 & 16 & $24 \cdot 3$ & $10 \cdot 23$ \\
\hline Burn's & 64 & $9 \cdot 33$ & $7 \cdot 75$ & 25 & $4 \cdot 66$ & 7 & 12 & 13 & 41345 & $10 \cdot 7$ \\
\hline EastCrinnis, Hudson's & 76 & $10 \cdot 25$ & $7 \cdot 16$ & $\begin{array}{l}70, \text { each } \\
26\end{array}$ & .5 & 10 & 14 & 16 & $74086 \cdot 1$ & $11 \cdot 4$ \\
\hline Huel Vor, Trelawny's & 80 & 10 & $7 \cdot 5$ & $\begin{array}{c}\mathrm{two} \text {, each } \\
24\end{array}$ & $-3 \cdot 5$ & 9 & 14 & 16 & 98770 & $14 \cdot 7_{+}^{+}$ \\
\hline Borlase's & 80 & 10 & 8 & $\left|\begin{array}{c}\text { twc, each } \\
24\end{array}\right|$ & 4 & 10 & 14 & 16 & 76010 & $12 \cdot 1 \ddagger$ \\
\hline
\end{tabular}

* In the progress of my experiment, the saw-dust on the cylinder-cover ignited several times. The influence exercised on the steam within the cylinders by the media with which they were surrounded, may be discovered by an inspection of the diagrams. (Trans. Inst. C. E. Vol. ii. Figs. 4., \&c., Pl. IV.)

+ The stroke in this pump is but $5 \cdot 5$ feet.

+ From Captain Lean's "Monthly Reports." 


\section{'Table II.-(Variables.)}

\section{Quantities of water and steam, pressures of steam, and tempera- tures.}

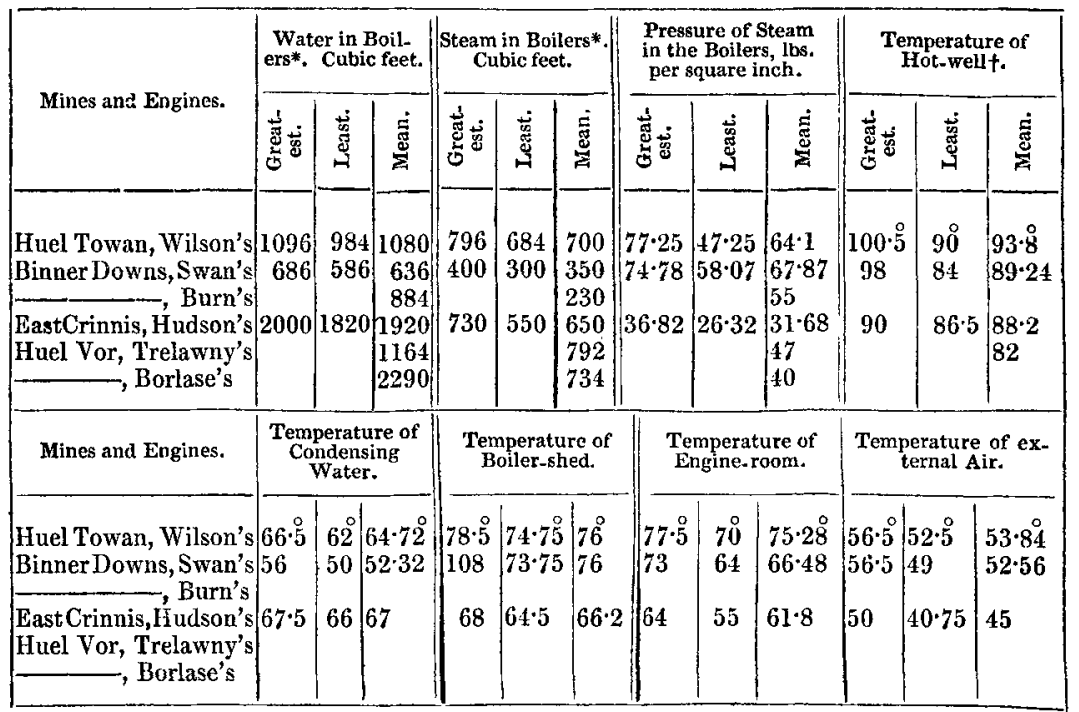

\section{Note to Table II.}

The following are the dimensions of the heating surfaces of the boilers of the three engines which were the principal subjects of my experiments. I add those of Loam's engine, on the United Mines, (with which I have been favoured by William Francis, Esq., the scientific director of that extensive mining establishment, ) as the only machine the evaporation in which has been published. See Mr. Lean's Report in the Cornwall Polytechnic Society's Transactions, IV. (1836) p. 34.

\begin{tabular}{|c|c|c|c|}
\hline Mines and Engines. & Area of the & $\begin{array}{c}\text { Surface exposed } \\
\text { to action of } \\
\text { the flame. }\end{array}$ & $\begin{array}{c}\text { Total heating } \\
\text { Surface exposed. }\end{array}$ \\
\hline Huel Towan, Wilson's Engine. & $\mathbf{7 2}$ & $\mathbf{F e e t .}$ & Feet. \\
Binner Downs, Swan's ......... & 48 & $\mathbf{1 1 4}$ & 2600 \\
East Crinnis, Hudson's ......... & $\mathbf{3 7 . 5}$ & $\mathbf{7 6}$ & $\mathbf{1 4 4 0}$ \\
United Mines, Loam's ......... & 49.5 & $\mathbf{5 7}$ & 2500 \\
& & 98 & 2310 \\
\hline
\end{tabular}

Loam's engine, at the United Mines, has the steam cylinder of 85 inches in diameter, the stroke in it is 10 feet, and in the pump 7.5 feet; the load is about $12 \mathrm{lbs}$. per square inch of the area of the piston, and the velocity about $4 \cdot 8$ strokes per minute : the elasticity of the steam employed I am

* The bnilers were, of course, always full of water and steam; and as the quantity of one increased, that of the other diminished, and vice versâ.

$\dagger$ As the pressure of the steam in the boilers increased, the temperature of the hot-well declined; so that by observing the alteration in one, that of the other could be predicted with great certainty. 


\section{$488 \mathrm{Mr}$. Henwood on the Cornish Pumping-Engines.}

unable to state. From the 2nd of March to the 5th of August, 1836, the duty was about 65 millions of pounds lifted one foot, by $100 \mathrm{lbs}$. of coal, and the evaporation by the same quantity of fuel for the same period was 15.4 cubic feet. This is a sufficient approximation to the result which I had five years previously obtained at Huel Towan.

The stroke in the cylinder of Loam's engine is estimated at 10 feet; an apparatus is fixed on it for registering the actual space passed over, and the mean for five months was 9.913 feet.

Table III.-(Constants.)

Dimensions of the Pumps.

\begin{tabular}{|c|c|c|c|c|c|c|c|c|c|}
\hline & \multicolumn{3}{|c|}{$\begin{array}{l}\text { Huel Towan, Wilson's } \\
\text { Engine. }\end{array}$} & \multicolumn{3}{|c|}{$\begin{array}{c}\text { Binner Downs, Swan's } \\
\text { Engine. }\end{array}$} & \multicolumn{3}{|c|}{$\begin{array}{c}\text { East Crinnis, Hudson's } \\
\text { Engine. }\end{array}$} \\
\hline & $\begin{array}{c}\text { Length } \\
\text { of } \\
\text { Pump. } \\
\text { F eet. }\end{array}$ & $\begin{array}{c}\text { Diame- } \\
\text { ter of } \\
\text { Pump. } \\
\text { Inches. }\end{array}$ & $\begin{array}{l}\text { Temper- } \\
\text { ature of } \\
\text { water in } \\
\text { Pump * }\end{array}$ & $\begin{array}{c}\text { Length } \\
\text { of } \\
\text { oump. } \\
\text { Feet. }\end{array}$ & $\begin{array}{l}\text { Diame- } \\
\text { ter of } \\
\text { Pump. } \\
\text { Inches. }\end{array}$ & $\begin{array}{l}\text { Temper- } \\
\text { ature of } \\
\text { water in } \\
\text { Pump*. }\end{array}$ & $\begin{array}{c}\text { Length } \\
\text { of } \\
\text { Pump. } \\
\text { Feet. }\end{array}$ & 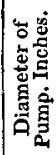 & 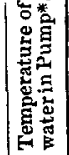 \\
\hline 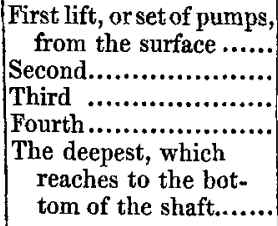 & $\begin{array}{l}265 \cdot 75 \\
263 \cdot 75 \\
197 \cdot 75 \\
113 \cdot 66\end{array}$ & $\begin{array}{l}13 \\
15 \cdot 875 \\
16 \cdot 125 \\
16 \cdot 125 \\
\\
12.5\end{array}$ & $\begin{array}{l}71 \cdot 125 \\
71 \cdot 75 \\
71 \cdot 875 \\
72 \cdot 25\end{array}$ & $\begin{array}{c}21 \cdot 25 \dagger \\
242 \cdot 66\end{array}$ & $\begin{array}{l}10^{\circ} \\
18 \cdot 875\end{array}$ & $\begin{array}{l}89 \cdot 24+ \\
72 \cdot 5\end{array}$ & $\begin{array}{r}39 \cdot 16 \\
159 \cdot 25 \\
269 \cdot 66 \\
198 \cdot 583\end{array}$ & $\begin{array}{l}13 \\
18 \\
18 \\
17\end{array}$ & $\begin{array}{l}63 \\
63 \\
63 \\
62 \cdot 5\end{array}$ \\
\hline
\end{tabular}

The whole loads of the three engines of which it was intended to ascertain the duty were raised perpendicularly, except the deepest lift of Wilson's engine at Huel Towan; and this was inclined to the horizon about $70^{\circ}$, and was connected to the engine-rod by a chain passing over two small wheels respectively of 9 and 16 inches in diameter.

The lowest lifts at Huel Towan and East Crinris were lifting pumps, and their loads were raised by the working strokes of their respective engines. All the other pumps were forcing pumps (plungers), and their columns were lifted during the return strokes of the engines, by the weight of the rods $\S$.

At Huel Towan, from the surface to a depth of about 534 feet, the connecting rods were 14 inches square; and from

* No correction has been applied for tempcrature, nor for impurities contained in the water. At Huel Towan I found, by evaporation, that about 360 grains were contained in a cubic foot. The temperature is higher as we descend; which adds to the already abundant evidence of the great heat prevailing in the interior of the earth.

+ The stroke in this pump is but $5^{.} 5$ feet.

+ This lift took its supply from the hot-well.

\$ The rods are usually very much heavier than the column of water, and a counterpoise is applied to balance some part of their weight: such was the case in all the engines here mentioned. 
that place downward they extended about 300 feet, and were 12 inches square. They were kept in their places by thirteen sets of guides, which exposed a surface of about 53.5 square feet*.

From the surface to 396 feet deep in Binner Downs, the rods were 14, inches square; and from thence downward, there were about 258 feet of 12 inch rods; these were also retained by thirteen sets of stays, having an area of about $35^{\circ} 6$ feet.

The rods, from the surface to 470 feet deep in East Crinnis, were 15 inches square, and thence about 200 feet deeper they were 12 inches: eleven sets of stays retained them in their places, and exposed a surface of about 38.8 feet.

Where the rods touch the stays they are protected by thin planks of some hard wood, which are always well covered with grease; they seldom fit very accurately.

TABLE IV.

Duration of the experiments, number of strokes made, materials consumed, \&c.

\begin{tabular}{|c|c|c|c|c|c|c|c|c|c|c|c|c|c|c|}
\hline \multirow[b]{2}{*}{$\begin{array}{c}\text { Mines and } \\
\text { Engines. }\end{array}$} & \multirow[b]{2}{*}{$\begin{array}{c}\text { Duration of } \\
\text { Experiments. }\end{array}$} & \multicolumn{2}{|c|}{$\begin{array}{c}\text { Coal } \\
\text { consumed. }\end{array}$} & \multirow{2}{*}{ 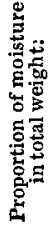 } & \multirow{2}{*}{ 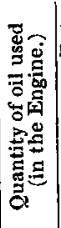 } & \multicolumn{2}{|c|}{$\begin{array}{l}\text { Quantity of } \\
\text { grease used. }\end{array}$} & \multirow{2}{*}{ 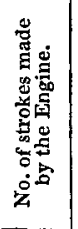 } & \multirow{2}{*}{ 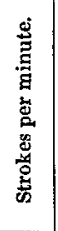 } & \multirow{2}{*}{ 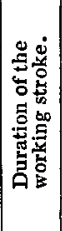 } & \multirow[b]{2}{*}{ 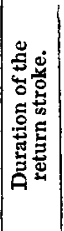 } & \multirow{2}{*}{ 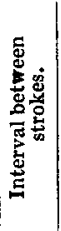 } & \multirow{2}{*}{ 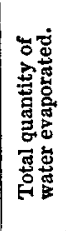 } & \multirow{2}{*}{ 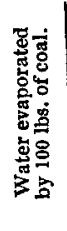 } \\
\hline & & 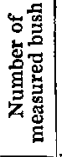 & 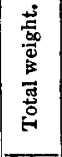 & & & 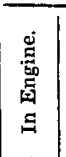 & 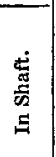 & & & & & & & \\
\hline Hue & \begin{tabular}{|cl}
1831. & h.m. \\
22 Nov. & 232 P.M.
\end{tabular} & & $1 \mathrm{bs}$. & & pint. & lbs. & lbs. & & & s. & s. & s. & & $\begin{array}{l}\text { Cubic } \\
\text { Feet. }\end{array}$ \\
\hline $\begin{array}{l}\text { Towan, } \\
\text { Wilson's. }\end{array}$ & to 23 Nov. 3 5 P.M. & 50 & 5003 & $\frac{1}{16}$ & 1 & 17 & 3 & 7881 & $5 \cdot 35$ & $1 \cdot 6$ & $4 \cdot 8$ & $4 \cdot 8$ & 847.5 & 16.95 \\
\hline $\begin{array}{l}\text { Binner } \\
\text { Downs, }\end{array}$ & c. 105 & 60 & 5561 & $\frac{\mathrm{t}}{T^{0}}$ & 1 & $12 \cdot 5$ & 3 & 11258 & $7 \cdot 49$ & $1 \cdot 34$ & $4 \cdot 23$ & $2 \cdot 4$ & & \\
\hline $\begin{array}{c}\text { Swan's } \\
\text { East }\end{array}$ & to 9 Dec. $\begin{array}{rr}0 & 2 \text { P.м. } \\
30 \text { Nov. } & 928 \text { A.M. }\end{array}$ & & & & & & & & & & & & & \\
\hline $\begin{array}{l}\text { Crinnis, } \\
\text { Hudson's }\end{array}$ & to 1 Dec. 755 A.M. & 34 & 3005 & $z^{\prime}$ & 1 & 12 & 5 & 4717 & 3.5 & $1 \cdot 7$ & $4 \cdot 17$ & $11 \cdot 2$ & & \\
\hline
\end{tabular}

The engines were taken without any previous preparation, and they were worked without intermission, at a speed just sufficient to keep the mines clear from water; but without permitting the pumps to draw air (go in fork). The workmen exercised their own discretion in the mode of working; for I purposely abstained from any other interference with them than was sufficient to satisfy myself that every thing was exposed to my notice, and fairly and honestly performed.

* The lengths of the lifts and of the rods do not coincide, because the former overlap each other in every case, in order that the higher pumps may draw out of the same cisterns into which the lower empty; and because the rods which take the different lifts are also doubled at the sets-off. 


\section{Mr. Henwood on the Cornish Pumping-Engines.}

'The results will appear in

TABLE V.

\begin{tabular}{|c|c|c|c|c|c|}
\hline Mines and Engines. & $\begin{array}{c}\text { Weight of the bush- } \\
\text { el of Coal. }\end{array}$ & $\begin{array}{c}\text { Duty (in lbs. lifted one foot high) performed } \\
\text { by each bushel of Coal*. }\end{array}$ \\
\cline { 2 - 7 } & $\begin{array}{c}\text { As taken } \\
\text { from the } \\
\text { heap. }\end{array}$ & $\begin{array}{c}\text { When } \\
\text { dry. }\end{array}$ & $\begin{array}{c}\text { Bushel } \\
\text { measured. }\end{array}$ & $\begin{array}{c}\text { 84 lbs, as taken } \\
\text { from the heap. }\end{array}$ & 84 lbs. dry. \\
\hline & lbs. & lbs. & & & \\
\hline & & & & \\
Huel Towan, Wilson's & 100 & $93 \cdot 8$ & $86,585,079$ & $72,687,853$ & $77,533,710$ \\
Binner Downs, Swan's & $92 \cdot 6$ & $83 \cdot 4$ & $73,877,810$ & $66,956,572$ & $74,395,923$ \\
East Crinnis, Hudson's & $88 \cdot 3$ & $84 \cdot 1$ & $73,954,606$ & $70,003,555$ & $73,502,699$ \\
\hline
\end{tabular}

III.-The work accomplished for a certain expense.-The foregoing details supply all that is requisite for this inquiry, except the prices of the materials consumed; these were coal, at the rate of forty-one shillings for 72 measured bushels $†$; grease, forty-five shillings and sixpence per $112 \mathrm{lbs}$; and oil, four shillings and twopence per gallon; at which rates the results were by Huel Towan, Wilson's engine, 1085 tons; Binner Downs, Swan's engine, 1006 tons; East Crinnis, Hudson's engine, 870 tons; lifted one foot high for the expense of one farthing.

As supplementary to the general object of the first part of this inquiry, it may be useful to compare the maxima of pressures which obtain in the cylinders, with known elasticities in the boilers; the loads of the engines remaining unchanged.

TABLE VI.-Load of engines, and relative pressures of steam in the boilers and cylinders.

\begin{tabular}{|c|c|c|c|}
\hline \multirow{2}{*}{ Mines and Engines. } & \multirow{2}{*}{$\begin{array}{l}\text { Load on the } \\
\text { Piston, in lbs. } \\
\text { per square } \\
\text { inch of } \\
\text { its area. }\end{array}$} & \multicolumn{2}{|c|}{$\begin{array}{l}\text { Pressure of steam in lbs. per } \\
\text { square inch. }\end{array}$} \\
\hline & & In the Boiler. & $\begin{array}{l}\text { In the Cylin- } \\
\text { der } \$ \text {. }\end{array}$ \\
\hline Huel Towan, Wilson's + & $10 \cdot 2$ & $61 \cdot 8$ & 27 \\
\hline Binner Downs, Swan's & $10 \cdot 23$ & $\left\{\begin{array}{l}74 \cdot 78 \\
58\end{array}\right.$ & $\begin{array}{l}26 \\
25\end{array}$ \\
\hline _ Burn's & $10 \cdot 7$ & & $30 \cdot 5$ \\
\hline East Crinnis, Hudson's & $11 \cdot 4$ & $\left\{\begin{array}{l}36 \cdot 8 \\
26 \cdot 3\end{array}\right.$ & $\begin{array}{l}25 \\
21\end{array}$ \\
\hline $\begin{array}{l}\text { Huel Vor, Trelawny's } \\
-, \text { Borlase's }\end{array}$ & $\begin{array}{l}14 \cdot 7 \\
12 \cdot 1\end{array}$ & $\begin{array}{l}47 \\
40\end{array}$ & $\begin{array}{l}30 \cdot 5 \\
30 \cdot 5\end{array}$ \\
\hline
\end{tabular}

- These numbers are on the assumption that each pump delivers the full computed quantity : but in an experiment at Huel Towan, made by Sir John Rennie and myself, the actual compared with the calculated delivery was as 0.924 to unity. I have repeated the comparison at the same place, with a similar result.

$\uparrow$ The bushel measure with a heaped head is the same which was used in Mr. Watt's time, varying only as prescribed by law.

I The figure in p. 482 refers to this engine.

$\S$ All the pressures mentioned throughout this paper are absolute, and as if acting against a vacuum. 
Many subjects which are yet undetermined have pressed on my attention during these experiments, among which the steam-case and air-pump are not the least important.

If any condensation take place in the case, when protected from the influence of the external air, it must be by radiation to the rarer steam within the cylinder. Now such influence, if exerted during at least two-thirds of every stroke*, would not only not increase the force of the engine by adding to the elasticity of the steam, but would render requisite the injection of a larger quantity of cold water into the condenser to effect condensation, and thereby add to the burden of the air-pumpt.

There must be a point at which the resistance of vapour, not abstracted, to the descent of the piston, and the pressure of the atmosphere on the air-pump whilst discharging its load, are at a minimum. Beyond this, if it be attempted to reduce the force of the vapour, by injecting more cold water, the burden of the air-pump is increased by the exposure of its piston to the atmosphere for a longer time during its discharge ; whilst on the other hand, if it be sought to lessen the duration of atmospheric pressure on the air-pump, by diminishing the quantity of cold water introduced into the condenser, the increased elasticity of the unabstracted vapour offers a greater resistance to the descent of the piston + .

This subject presents many inviting topics of inquiry; but the pursuit of them, and the earlier preparation of the details $\$$ which I have now the honour to submit to the Institution, have been prevented by more pressing occupations.

4, Clarence Street, Penzance,

W. J. HENWOOD. August 3oth, 1837.

* See Table IV.

+ Brewster's Edinburgh Journal of Science, O. S. IX., p. 162.

$\neq$ Ibid., X. p. 40.

$\$$ A short notice of these experiments appeared in Brewster's Edinburgh Journal of Science, N. S., VI. p. 246. 